\title{
PERTUMBUHAN TANAMAN KANGKUNG DARAT( Ipomoea reptans Poir.) DEN- GAN PEMBERIAN PUPUK ORGANIK BERBAHAN DASAR KOTORAN KELINCI
}

\author{
Irawati, Zuchrotus Salamah
}

\section{ABSTRAK}

$\mathrm{P}$ enelitian ini bertujuan untuk mengetahui pertumbuhan tanaman kangkung darat dengan pemberian pupuk organik berbahan dasar kotoran kelinci dan untuk mengetahui dosis kompos yang tepat untuk pertumbuhan tanaman kangkung darat serta untuk mengetahui apakah hasil penelitian ini dapat digunakan sebagai sumber belajar siswa SMA kelas XII pada materi pembelajaran pertumbuhan tumbuhan.

Penelitian ini termasuk jenis penelitian eksperimen yang menggunakan Rancangan Acak Lengkap (RAL) dengan satu faktor yaitu dosis kompos terdiri dari 5 perlakuan yaitu: $\mathrm{D} 1=20 \mathrm{~g} / 3 \mathrm{~kg}$ tanah, D2=40 g/3 $\mathrm{kg}$ tanah, D3=60 g/3 kg tanah, D4=40 g/3 kg tanah, D5=100 $\mathrm{g} / 3 \mathrm{~kg}$ tanah masing-masing dengan 4 kali ulangan. Parameter pertumbuhan tanaman yang diukur meliputi tinggi tanaman, jumlah daun, panjang daun, panjang akar, berat basah dan berat kering tanaman. Untuk mengetahui hasil penelitian diuji dengan Analisis Varian (ANAVA) dan apabila ada perbedaan maka dilanjutkan dengan uji BNT pada taraf 5\%.

Pertumbuhan tanaman kangkung darat dengan pemberian pupuk organik berbahan dasar kotoran kelinci yang berbeda-beda menunjukkan hasil yang berbeda pula. Dosis kompos yang tepat untuk pertumbuhan tanaman kangkung darat adalah $60 \mathrm{~g} / 3 \mathrm{~kg}$ tanah. Hasil penelitian ini melalui metode pengkajian diharapkan dapat digunakan sebagai sumber belajar siswa SMA kelas XII pada materi pembelajaran pertumbuhan tumbuhan.

Kata kunci : Pertumbuhan, Kangkung Darat (Ipomoea reptans, Poir.), Kotoran Kelinci 


\section{PENDAHULUAN}

Kangkung merupakan jenis sayuran yang sudah dikenal oleh seluruh lapisan masyarakat Indonesia, kangkung darat merupakan tanaman berumur pendek, yang mengandung gizi cukup tinggi, yaitu vitamin A, $\mathrm{B}, \mathrm{C}$, protein, kalsium, fosfor, sitosterol dan bahan-bahan mineral terutama zat besi yang berguna bagi pertumbuhan badan dan kesehatan (Anonim, 2000).

Sayuran ini dapat tumbuh dengan baik di pekarangan rumah, maupun areal persawahan. Kangkung juga dapat hidup dengan baik di daratan tinggi maupun daratan rendah sehingga hampir di seluruh tanah air kita tanaman ini dapat dibudidayakan. Selain itu tanaman kangkung darat dapat ditanam di daerah yang beriklim panas maupun lembab, serta tumbuh baik pada tanah yang kaya bahan organik dan unsur hara yang cukup, sehingga dalam pembudidayaan kangkung membutuhkan pupuk untuk mengoptimalkan pertumbuhan dan hasil panen (Rukmana, 1994).

Keperluan tanaman akan pupuk sama halnya dengan keperluan manusia akan makanan. Selain pemupukan dari luar, tanah telah menyediakan hara dan mineral yang cocok untuk tanaman. Namun, dalam jangka panjang persediaan hara dalam tanah semakin berkurang akibatnya terjadi ketida- kseimbangan antara penyerapan hara yang cepat dengan pembentukan hara yang lambat. Oleh karena itu, pemupukan merupakan suatu keharusan dalam sistem pertanian (Setiawan, 2005).

Pupuk yang digunakan bisa berupa pupuk organik atau pupuk anorganik. Penggunaan pupuk anorganik secara terus menerus akan berdampak negatif terhadap produktivitas tanah. Karena itu, memupuk tanaman lebih dianjurkan menggunakan pupuk organik. Pupuk organik dapat berupa kompos, pupuk kandang, pupuk hijau dan pupuk organik cair. Bahan baku pupuk organik sangat mudah diperoleh karena memanfaatkan sampah organik yang berada disekitar lingkungan. Seperti kotoran kelinci, tumpukan kotoran kelinci yang dibiarkan begitu saja menyebabkan pencemaran lingkungan serta dapat mengganggu kesehatan.

Kotoran kelinci mengandung berbagai kandungan kimia yang sangat bermanfaat bagi tanaman. Unsur nitrogen yang terdapat pada kotoran kelinci menyebabkan daun menjadi lebih besar dan berwarna hijau tua. Unsur fosfor berperan dalam proses fotosintesis sedangkan magnesium merupakan salah satu unsur hara makro yang diperlukan tanaman sebagai unsur pembentukan klorofil. Pertumbuhan jumlah daun sejalan dengan bertambahnya umur tanaman. Semakin tua suatu tanaman maka makin banyak tunas 
yang muncul sehingga jumlah daun semakin banyak (Salisbury dan Ross, 1995).

\section{METODE PENELITIAN}

Penelitian ini dilaksanakan di desa Glagahsari kecamatan Umbulharjo Yogyakarta. Waktu penelitian dilaksanakan pada bulan November - Desember 2010. Alat yang digunakan dalam penelitian ini adalah timbangan, gelas, baskom, saringan, ukur, mistar, oven, termometer, kertas label, besek, $\mathrm{pH}$ universal, higrometer, hand sprayer, plastik dan bambu untuk rumah penanaman, polybag dengan ukuran 30x30 cm sebanyak 24 buah. Bahan yang digunakan dalam penelitian ini adalah kotoran kelinci, benih kangkung darat (Ipomoea reptans, Poir.), air sumur untuk menyiram tanaman, dan tanah sebagai media tanam.

Variabel bebas meliputi kotoran kelinci dengan dosis kompos kotoran kelinci, dalam penelitian ini yang digunakan adalah $\mathrm{D} 0=0 \mathrm{~g}$ (kontrol), D1 = $20 \mathrm{~g}, \mathrm{D} 2=40 \mathrm{~g}, \mathrm{D} 3$ $=60 \mathrm{~g}, \mathrm{D} 4=80 \mathrm{~g}, \mathrm{D} 5=100 \mathrm{~g}$. Variabel terikat dalam penelitian ini meliputi tinggi tanaman, jumlah daun, berat basah, panjang akar, dan berat kering tumbuhan.

Persiapan

Pembuatan Kompos

1). Semua bahan cair dicampur (EM4 sebanyak 3 sendok dan air sebanyak 1 liter) dengan gula putih (2 sendok) kemudian di aduk rata.

2). Campuran bahan padat (kotoran kelinci) di siram dengan campuran bahan cair (EM4, air dan gula putih), kemudian diaduk hingga tercampur rata. Kadar air campuran bahan sekitar $30-40 \%$ yang ditandai dengan tidak adanya tetesan air jika bahan di genggam dan akan mekar jika genggaman bahan dilepas.

3). Bahan - bahan yang sudah dicampur dimasukan ke dalam karung, kemudian ujung karung diikat.

4). Suhu kompos dipertahankan 40-500C, suhu di kontrol setiap hari dengan cara mengaduk bahan tersebut agar suhunya tidak tinggi.

5). Setelah 10 hari, bila kompos sudah matang sesuai dengan ciri-ciri sebagai berikut: jika diraba suhu tumpukan bahan yang dikomposkan sudah dingin (mendekati suhu ruang), tidak mengeluarkan bau busuk, berwarna kehitaman, dan jika dilarutkan dalam air tidak akan larut. Maka kompos sudah siap untuk digunakan.

6). Kompos yang sudah jadi di analisis kandungan unsur haranya di Laboratorium Balai Teknik Kesehatan Lingkungan dan Pemberantasan Penyakit Menular Yogyakarta.

\section{Perhitungan Dosis kompos}

Penggunaan kompos sebagai pupuk 
tidak berbeda dengan pupuk kandang, dosisnya pun sama dengan pupuk kandang sekitar 20 ton/ha (Lingga dan Marsono, 2008).

1). Kompos per ha per tahun $=20$ ton $=20.000 \mathrm{~kg}$

Luas lahan $1 \mathrm{ha}=10.000 \mathrm{~m} 2$

Tebal tanah olahan $10 \mathrm{~cm}=0,1 \mathrm{~m}$

Isi tanah 1 ha $=10.000 \mathrm{~m} 2 \times 0,1 \mathrm{~m}$

$$
=1 \times 103 \times 103 \mathrm{dm} 3
$$

Berat tanah 1 ha = isi tanah $\mathrm{x}$ Bj tanah

$$
\begin{aligned}
& =1 \times 106 \mathrm{dm} 3 \times 1 \mathrm{~kg} / \mathrm{dm} 3 \\
& =1 \times 106 \mathrm{~kg}
\end{aligned}
$$

2). Dosis kompos untuk $1 \mathrm{~kg}$ tanah dosis kompos 1 ha x $1 \mathrm{~kg}$ tanah per berat.

Tanah 1 ha $=20.000 \times 1 / 100.000=0,02$ $\mathrm{kg}$ atau $20 \mathrm{gr}$.

Artinya untuk kompos 20 ton per ha, maka tiap $1 \mathrm{~kg}$ tanah olah dibutuhkan 0,02 $\mathrm{kg}$ atau $20 \mathrm{gr}$ kompos.

3). Perlakuan dosis kompos yang digunakan dalam penelitian.

Tanah yang digunakan dalam penelitian sebanyak $3 \mathrm{~kg}$ untuk setiap polybag.

Dosis kompos yang digunakan dalam penelitian yaitu D0 $=0 \mathrm{~g} / 3 \mathrm{~kg}$ tanah (kontrol), D1 = $20 \mathrm{~g} / 3 \mathrm{~kg}$ tanah, D2 $=40$ $\mathrm{g} / 3 \mathrm{~kg}$ tanah , D3 = $60 \mathrm{~g} / 3 \mathrm{~kg}$ tanah, D4 $=80 \mathrm{~g}, \mathrm{D} 5=100 \mathrm{~g} / 3 \mathrm{~kg}$ tanah.

\section{Pembuatan rumah plastik}

Dalam penelitian ini digunakan rumah plastik dengan ukuran $3 \times 2$ m yang bertujuan untuk melindungi tanaman dari hama penyakit dan mengurangi resiko gangguan pertumbuhan akibat faktor alam dan lingkungan, rumah plastik di buat dari plastik dan bambu untuk penyangga.

\section{Persiapan media}

Tanah dibersihkan dari kerikil dan rerumputan, kemudian ditimbang sebanyak $3 \mathrm{~kg}$. Tanah kemudian dicampur dengan kompos sesuai dengan dosis masing-masing. Tanah yang telah tercampur di masukan dalam polybag ukuran 30 x $30 \mathrm{~cm}$. Media siap untuk ditanam.

\section{Pemilihan benih}

Benih kangkung darat dipilih yang baik dengan cara disortir, salah satu cara untuk mengetahui adalah dengan cara merendamnya dengan dalam air, jika biji terapung maka biji tersebut tidak baik untuk digunakan.

\section{Persemaian}

Benih tanaman kangkung darat yang baik disebar pada besek (tempat persemaian) yang telah di berisi campuran tanah dan pupuk kandang. Setelah 1 minggu benih yang tumbuh baik dan telah memiliki 3 daun pertama semai yang seragam, tanaman baru dipindahkan dalam polybag ukuran $30 \times 30$ $\mathrm{cm}$ yang telah diberi isi media tanam di beri label atau tanda untuk masing-masing perlakuan. 


\section{Pelaksanaan penelitian}

\section{Penanaman}

Tanaman kangkung darat umur 7 hari dimasukkan dalam polybag yang telah disediakan dengan mencabut bibit secara hatihati (pelan). Agar pencabutan tidak merusak perakaran tanaman. Dipilih bibit tanaman yang memiliki tinggi seragam. Setiap media tanam (polybag yang sudah dicampurkan dengan sesuai dengan dosis masing-masing) di isi satu tanaman.

\section{Pemeliharaan}

Tanaman disiram dengan air sumur setiap pagi dan sore dengan volume air 100 $\mathrm{ml}$ setiap polybag dilakukan setiap hari pada saat penanaman sampai panen. Untuk menjaga persaingan dan kualitas tanah dilakukan penyiangan terhadap tanaman pengganggu lain (gulma).

\section{Pengamatan}

\section{Tinggi tanaman $(\mathrm{cm})$}

Tinggi tanaman diukur dari pangkal tanaman sampai ujung daun dengan menggunakan penggaris. Data tinggi tanaman kemudian dicatat dan dikelompokkan sesuai dengan kode atau label yang tertera pada tanaman tersebut. Pengukuran dilakukan seminggu sekali.

\section{Jumlah daun (helai)}

Jumlah daun dihitung daun yang terbuka lebar, daun yang kuning dan layu atau menguning tidak diperhitungkan. Pen- gamatan ini dilakukan seminggu sekali.

\section{Panjang daun}

Panjang daun diukur pada 3 helai daun di pilih yang sehat dan baik dari masing - masing tanaman, di ukur dari pangkal daun hingga ujung daun, pengamatan dilakukan seminggu sekali.

\section{Panjang akar}

Panjang akar diukur pada pangkal hingga ujung dari akar pokok, pengamatan dilakukan setelah penelitian berakhir

\section{Berat basah}

Berat basah yaitu berat keseluruhan bagian tanaman segar tanpa pengeringan. Akar, batang dan daun tanaman yang telah dicuci, ditiriskan. Air yang masih melekat diangin - anginkan lalu timbang secara keseluruhan. Penimbangan ini dilakukan diakhir penelitian.

\section{Berat kering}

Berat kering di peroleh dengan cara di timbang berat kering kangkung darat. Akar, batang, dan daun tanaman dimasukkan dalam lipatan kertas/amplop yang berbeda. Pengamatan tanaman dilakukan pada minggu terakhir, dioven dengan suhu 80 0C selama 2 × 24 jam.

\section{Pengukuran kondisi abiotik}

Pengukuran derajat keasaman $(\mathrm{pH})$ media tanam dilakukan dengan menggunakan $\mathrm{pH}$ meter pada media sebelum diberi kon- 
sentrasi kotoran kelinci dan media setelah diberi konsentrasi kotoran kelinci.

Pengukuran suhu lingkungan tempat pemeliharaan tanaman kangkung darat dengan menggunakan termometer, dilakukan setiap seminggu sekali pada pagi hari jam 06.30, siang hari jam 12.00 dan sore hari jam 16.30 .

Pengukuran kelembaban lingkungan tempat pemeliharan tanaman kangkung darat di ukur dengan menggunakan higrometer, dilakukan setiap seminggu sekali pada pagi hari jam 06. 30, siang hari jam 12.00 dan sore hari jam 16.30.

Penelitian disusun secara Rancangan Acak Lengkap (RAL) yang terdiri dari satu faktor perlakuan yaitu dosis kotoran kelinci yang terdiri dari 6 dosis yaitu : D0 $=0 \mathrm{~g} / 3$ $\mathrm{kg}$ tanah (kontrol), D1 = $20 \mathrm{~g} / 3 \mathrm{~kg}$ tanah, $\mathrm{D} 2=40 \mathrm{~g} / 3 \mathrm{~kg}$ tanah , D3 = $60 \mathrm{~g} / 3 \mathrm{~kg}$ tanah, D4 = $80 \mathrm{~g} / 3 \mathrm{~kg}$ tanah, D5 = $100 \mathrm{~g} /$ $3 \mathrm{~kg}$ tanah masing - masing perlakuan dengan 4 kali ulangan, sehingga terdapat 24 unit percobaan.

Data hasil percobaan di analisis dengan uji Analisis Varian (Anava) untuk mengetahui perbedaan antar perlakuan. Apabila hasil analisis ada perbedaan nyata dilanjutkan dengan uji BNT pada taraf 5\% untuk mengetahui letak perbedaannya.

Hasil penelitian sebagai sumber belajar Biologi di SMA kelas XII untuk menca- pai standar kompetensi berupa media pembelajaran dalam bentuk Power Point pada materi pertumbuhan tumbuhan

\section{HASIL DAN PEMBAHASAN}

Kandungan unsur hara yang dianalisis dalam pupuk berbahan dasar kotoran kelinci adalah: C (Karbon), N (Nitrogen), P (Posfor) dan K (Kalium). Adapun analisis pupuk berbahan dasar kotoran kelinci dapat dilihat pada Tabel 3. berikut ini:

\begin{tabular}{|l|c|}
\hline \multicolumn{1}{|c|}{ Parameter } & Hasil Uji (\%) \\
\hline $\mathrm{N}$ (Nitrogen) & 2,34 \\
\hline P (Posfor) & 0,13 \\
\hline K (Kalium) & 0,84 \\
\hline
\end{tabular}

Tabel 3. Hasil Uji Kandungan Unsur N, P dan K Pupuk KotoranKelinci

Hasil pengukuran tinggi tanaman kangkung darat dari beberapa perlakuan menunjukkan adanya perbedaan rerata tinggi tanaman kangkung darat dapat dilihat pada tabel 4. Berikut.

\begin{tabular}{|c|c|c|}
\hline $\begin{array}{c}\text { Perla- } \\
\text { kuan }\end{array}$ & $\begin{array}{c}\text { Rerata Tinggi } \\
\text { Tanaman }(\mathrm{cm})\end{array}$ & $\begin{array}{c}\text { BNT }(0,05)= \\
0,11\end{array}$ \\
\hline $\mathrm{D}_{0}$ & 30.69 & $\mathrm{a}$ \\
\hline $\mathrm{D}_{1}$ & 30.68 & $\mathrm{a}$ \\
\hline $\mathrm{D}_{2}$ & 31.07 & $\mathrm{~b}$ \\
\hline $\mathrm{D}_{3}$ & 31.70 & $\mathrm{c}$ \\
\hline $\mathrm{D}_{4}$ & 31.09 & $\mathrm{~b}$ \\
\hline $\mathrm{D}_{5}$ & 30.62 & $\mathrm{a}$ \\
\hline
\end{tabular}

Tabel 4. Hasil Perhitungan Rerata Tinggi Tanaman Kangkung Darat Minggu Ke-1- sampai ke-6 


\begin{tabular}{|c|c|c|c|c|c|c|}
\hline \multirow{2}{*}{$\begin{array}{c}\text { Perla- } \\
\text { kuan }\end{array}$} & \multicolumn{7}{|c|}{ Minggu Ke $(\mathrm{cm})$} \\
\cline { 2 - 7 } & 1 & 2 & 3 & 4 & 5 & 6 \\
\hline $\mathrm{D}_{0}$ & 8,24 & 9,98 & 15,24 & 20,26 & 25,9 & 30,70 \\
\hline $\mathrm{D}_{1}$ & 8,74 & 10,16 & 16,16 & 21,77 & 28,42 & 30,69 \\
\hline $\mathrm{D}_{2}$ & 8,94 & 11,24 & 17,02 & 22,16 & 29,56 & 31,08 \\
\hline $\mathrm{D}_{3}$ & 9,58 & 11,48 & 18,46 & 24,56 & 31,04 & 31,70 \\
\hline $\mathrm{D}_{4}$ & 7,78 & 9,74 & 16,48 & 20,26 & 27,24 & 31,10 \\
\hline $\mathrm{D}_{5}$ & 7,6 & 9,26 & 14,02 & 19,74 & 24,4 & 30,62 \\
\hline
\end{tabular}

Keterangan :

D0 $=0 \mathrm{~g}$ (kontrol)

$\mathrm{D} 1=$ perlakuan dosis $20 \mathrm{~g}$

$\mathrm{D} 2=$ perlakuan dosis $40 \mathrm{~g}$

D3 = perlakuan dosis $60 \mathrm{~g}$

D4 = perlakuan dosis $80 \mathrm{~g}$

D5 = perlakuan dosis $100 \mathrm{~g}$

Perlakuan dosis pupuk kotoran kelinci memberikan perbedaan yang signifikan terhadap tinggi tanaman kangkung darat.

Untuk mengetahui perbedaan antara kelompok perlakuan maka dilanjutkan dengan uji BNT 5\% sebagai berikut :

\begin{tabular}{|c|c|c|c|c|c|c|}
\hline \multirow{2}{*}{$\begin{array}{l}\text { Perla- } \\
\text { kuan }\end{array}$} & \multicolumn{7}{|c|}{ Jumlah Daun (minggu) } \\
\cline { 2 - 7 } & 1 & 2 & 3 & 4 & 5 & 6 \\
\hline $\mathrm{D}_{0}$ & 4,6 & 5,4 & 6,6 & 9,4 & 16,2 & 24,2 \\
\hline $\mathrm{D}_{1}$ & 6,2 & 7,6 & 9,2 & 12,2 & 17,8 & 27,2 \\
\hline $\mathrm{D}_{2}$ & 5,8 & 6,2 & 8,2 & 11,2 & 19,2 & 25,4 \\
\hline $\mathrm{D}_{3}$ & 7,4 & 8,4 & 10,2 & 16,6 & 21,2 & 31 \\
\hline $\mathrm{D}_{4}$ & 7,6 & 8,6 & 11,4 & 15,8 & 25,4 & 27,4 \\
\hline $\mathrm{D}_{5}$ & 7,8 & 9 & 12,8 & 14 & 17,8 & 21,3 \\
\hline
\end{tabular}

Tabel 5. Hasil Uji BNT 5 \% Tinggi Tanaman Kangkung Darat Umur 6 Minggu

Tinggi tanaman kangkung darat setelah diberi pupuk kotoran kelinci dari berbagai perlakuan dosis kotoran kelinci menunjukkan adanya variasi. Pengaruh yang nyata pada perlakuan dosis $60 \mathrm{~g}$, dapat memacu pertumbuhan tinggi tanaman secara opti- mal.

Bertambahnya tinggi suatu tanaman merupakan hasil pertumbuhan organ batang tanaman. Pertumbuhan suatu organ tidak terlepas dari sel-sel penyusunnya. Pertumbuhan tinggi batang terjadi di dalam meristem interkalar dari ruas, ruas itu memanjang sebagai akibat meningkatnya jumlah dan meluasnya sel.

\section{Jumlah Daun}

Hasil pengukururan rerata jumlah daun tanaman kangkung darat (Ipomoea reptans, Poir.) dapat dilihat pada Tabel 7. sebagai berikut:

\begin{tabular}{|c|c|c|}
\hline Perlakuan & $\begin{array}{c}\text { Rerata Jumla Daun } \\
(\mathrm{cm})\end{array}$ & $\begin{array}{c}\text { BNT }(0.05)= \\
(0,77)\end{array}$ \\
\hline $\mathrm{D}_{0}$ & 24,2 & $\mathrm{~b}$ \\
\hline $\mathrm{D}_{1}$ & 27,7 & $\mathrm{~d}$ \\
\hline $\mathrm{D}_{2}$ & 25,4 & $\mathrm{c}$ \\
\hline $\mathrm{D}_{3}$ & 31,0 & $\mathrm{e}$ \\
\hline $\mathrm{D}_{4}$ & 27,4 & $\mathrm{~d}$ \\
\hline $\mathrm{D}_{5}$ & 21,3 & $\mathrm{a}$ \\
\hline
\end{tabular}

Tabel 6. Hasil Perhitungan Rerata Jumlah Daun Tanaman Kangkung Darat Minggu ke-1 Sampai Minggu ke-6

Keterangan:

$\mathrm{D} 0=0 \mathrm{~g}$ (kontrol)

$\mathrm{D} 1=$ perlakuan dosis $20 \mathrm{~g}$

D2 $=$ perlakuan dosis $40 \mathrm{~g}$

D3 = perlakuan dosis $60 \mathrm{~g}$

D4 = perlakuan dosis $80 \mathrm{~g}$

$\mathrm{D} 5=$ perlakuan dosis $100 \mathrm{~g}$

Perlakuan dosis kotoran kelinci memberikan perbedaan yang signifikan terhadap jumlah daun tanaman kangkung darat. Untuk men- 
getahui perbedaan antara perlakuan maka dilanjutkan dengan uji BNT 5\% sebagai berikut :

Tabel 7. Hasil Uji BNT 5 \% Jumlah Daun Kangkung Darat Umur 6 Minggu

Jumlah daun tanaman kangkung darat setelah diberi pupuk kotoran kelinci yang bervariasi memberikan pengaruh yang nyata pada perlakuan D3, hal ini dikarenakan adanya unsur nitrogen yang terkandung pada perlakuan D3(60g) sesuai untuk kebutuhan tanaman sehingga pertumbuhan tanamannya menjadi optimal.

Menurut Gardner, dkk. (1991) bahwa daun berfungsi sebagai organ utama fotosintesis pada tumbuhan tingkat tinggi. Umur daun mempengaruhi fotosintesis, proses penuaan menyebabkan kelambanan proses fotosintesis.

\section{Panjang Daun}

Hasil pengukuran terhadap panjang daun tanaman kangkung darat dari beberapa perlakuan menunjukkan adanya perbedaan, dapat dilihat sebagai berikut:

Tabel 8. Hasil Perhitungan Rerata Panjang Daun Kangkung Darat (Ipomoea reptans Poir.) Minggu Ke-1 sampai Ke-6

\begin{tabular}{|c|c|c|c|c|c|c|}
\hline \multirow{2}{*}{$\begin{array}{l}\text { Perla- } \\
\text { kuan }\end{array}$} & \multicolumn{6}{|c|}{ Umur Tanaman (minggu) } \\
\cline { 2 - 7 } & 1 & 2 & 3 & 4 & 5 & 6 \\
\hline $\mathrm{D}_{0}$ & 3,74 & 5,9 & 6,81 & 8,71 & 10,3 & 12,8 \\
\hline $\mathrm{D}_{1}$ & 4,84 & 6,5 & 7,57 & 8,22 & 11,9 & 13 \\
\hline $\mathrm{D}_{2}$ & 5,44 & 6,6 & 8,18 & 9,71 & 11,5 & 13,3 \\
\hline $\mathrm{D}_{3}$ & 6,2 & 6,9 & 10,7 & 12,5 & 14,3 & 14,7 \\
\hline $\mathrm{D}_{4}$ & 4,94 & 6,6 & 7,22 & 9,90 & 12,1 & 13,6 \\
\hline $\mathrm{D}_{5}$ & 3,92 & 6,8 & 8,18 & 10,3 & 12,3 & 13,1 \\
\hline
\end{tabular}

Keterangan:

D0 $=0 \mathrm{~g}$ (kontrol)

$\mathrm{D} 1=$ perlakuan dosis $20 \mathrm{~g}$

D2 $=$ perlakuan dosis $40 \mathrm{~g}$

D3 $=$ perlakuan dosis $60 \mathrm{~g}$

D4 $=$ perlakuan dosis $80 \mathrm{~g}$

D5 $=$ perlakuan dosis $100 \mathrm{~g}$

Perlakuan dosis pupuk kotoran kelinci memberikan perbedaan yang signifikan terhadap panjang daun tanaman kangkung darat. Untuk mengetahui perbedaan, maka dilanjutkan dengan uji BNT 5\% dengan hasil sebagai berikut :

\begin{tabular}{|c|c|c|}
\hline Perlakuan & $\begin{array}{c}\text { Rerata Jumla Daun } \\
(\mathrm{cm})\end{array}$ & $\begin{array}{c}\text { BNT }(0,05) \\
=0,00\end{array}$ \\
\hline $\mathrm{D}_{0}$ & 12,99 & $\mathrm{a}$ \\
\hline $\mathrm{D}_{1}$ & 12,99 & $\mathrm{a}$ \\
\hline $\mathrm{D}_{2}$ & 13 & $\mathrm{a}$ \\
\hline $\mathrm{D}_{3}$ & 14,33 & $\mathrm{~b}$ \\
\hline $\mathrm{D}_{4}$ & 12,99 & $\mathrm{a}$ \\
\hline $\mathrm{D}_{5}$ & 12,99 & $\mathrm{a}$ \\
\hline
\end{tabular}

Tabel 9. Hasil Uji BNT 5 \% Panjang

\section{Daun Kangkung Darat Umur 6 Minggu}

Pencapaian panjang daun setelah diberi pupuk kotoran kelinci yang bervariasi, menunjukkan yang paling panjang terdapat pada perlakuan D3 (60 g), hal ini disebabkan karena unsur hara yang terkandung pada perlakuan tersebut dapat memenuhi kebutuhan daun pada tanaman, sehingga pertumbuhan daun berlangsung baik. 


\section{Panjang Akar}

Hasil pengukuran terhadap Panjang akar tanaman kangkung darat dari beberapa perlakuan menunjukkan adanya perbedaan, dapat dilihat sebagai berikut:

\begin{tabular}{|c|c|}
\hline Perlakuan & $\begin{array}{c}\text { Rerata Panjang Akar } \\
\text { Tanaman }(\mathrm{cm})\end{array}$ \\
\hline $\mathrm{D}_{0}$ & 7,96 \\
\hline $\mathrm{D}_{1}$ & 8,05 \\
\hline $\mathrm{D}_{2}$ & 9,50 \\
\hline $\mathrm{D}_{3}$ & 11,25 \\
\hline $\mathrm{D}_{4}$ & 9,50 \\
\hline $\mathrm{D}_{5}$ & 8,11 \\
\hline
\end{tabular}

Tabel 10. Hasil Perhitungan Rerata Panjang Akar Tanaman Kangkung Darat (Ipomoea reptans, Poir.) Pada Minggu ke-1 sampai Ke-6

\section{Keterangan:}

$\mathrm{D} 0=0 \mathrm{~g}$ (kontrol)

$\mathrm{D} 1=$ perlakuan dosis $20 \mathrm{~g}$

$\mathrm{D} 2=$ perlakuan dosis $40 \mathrm{~g}$

D3 $=$ perlakuan dosis $60 \mathrm{~g}$

D4 = perlakuan dosis $80 \mathrm{~g}$

D5 $=$ perlakuan dosis $100 \mathrm{~g}$

Perlakuan dosis pupuk kotoran kelinci memberikan perbedaan yang signifikan terhadap panjang akar tanaman kangkung darat. Untuk mengetahui perbedaan antara perlakuan maka dilanjutkan dengan uji BNT 5\% dengan hasil sebagai berikut :

\begin{tabular}{|c|c|c|}
\hline Perlakuan & $\begin{array}{c}\text { Rerata Panjang } \\
\text { Akar }(\mathrm{cm})\end{array}$ & $\begin{array}{c}\text { BNT }(0,05)= \\
0,14\end{array}$ \\
\hline $\mathrm{D}_{0}$ & 7,95 & $\mathrm{a}$ \\
\hline $\mathrm{D}_{1}$ & 8,05 & $\mathrm{a}$ \\
\hline $\mathrm{D}_{2}$ & 9,50 & $\mathrm{~b}$ \\
\hline $\mathrm{D}_{3}$ & 11,25 & $\mathrm{c}$ \\
\hline $\mathrm{D}_{4}$ & 9,50 & $\mathrm{~b}$ \\
\hline $\mathrm{D}_{5}$ & 8,10 & $\mathrm{a}$ \\
\hline
\end{tabular}

\section{Tabel 11. Hasil Uji BNT 5 \% Panjang Akar Kangkung Darat pada Minggu ke-1 sampai Ke-6}

Pada perlakuan D3 (60g) terjadi keseimbangan antara unsur hara diantaranya unsur N, P, K, air dan kelembaban tanah. Dari analisis fermentasi pupuk dihasilkan unsur P yaitu 0,13\%. Keberadaan air dan unsur $\mathrm{P}$ akan mempermudah akar tumbuh lebih baik dalam tanah. Sedangkan unsur K penting untuk fungsi fisiologis tertentu pada akar dalam penyerapan, dan juga kelembaban akan mendukung fungsi fisiologis akar (Gardner, et al, 1991).

\section{Berat Basah}

Hasil pengukuran terhadap berat basah tanaman kangkung darat dari beberapa perlakuan menunjukkan adanya perbedaan, dapat dilihat pada Tabel 12. berikut ini:

\begin{tabular}{|c|c|}
\hline Perlakuan & $\begin{array}{c}\text { Rerata Berat Basah Tanaman } \\
\text { (gram) }\end{array}$ \\
\hline $\mathrm{D}_{0}$ & 13,40 \\
\hline $\mathrm{D}_{1}$ & 14,25 \\
\hline $\mathrm{D}_{2}$ & 34,60 \\
\hline $\mathrm{D}_{3}$ & 44,8 \\
\hline $\mathrm{D}_{4}$ & 34,45 \\
\hline $\mathrm{D}_{5}$ & 13,38 \\
\hline
\end{tabular}

Tabel 12. Hasil Perhitungan Rerata Berat Basah Tanaman Kangkung Darat (Ipomoea reptans, Poir.) Pada Minggu Ke-1 sampai Ke-6

\section{Keterangan:}

D0 $=0 \mathrm{~g}$ (kontrol)

$\mathrm{D} 1=$ perlakuan dosis $20 \mathrm{~g}$

$\mathrm{D} 2=$ perlakuan dosis $40 \mathrm{~g}$

D3 $=$ perlakuan dosis $60 \mathrm{~g}$

D4 = perlakuan dosis $80 \mathrm{~g}$

D5 = perlakuan dosis $100 \mathrm{~g}$

Perlakuan dosis pupuk kotoran kelinci memberikan perbedaan yang signifikan terhadap berat basah tanaman kangkung darat. Untuk mengetahui perbedaan antara perlakuan maka dilanjutkan dengan uji BNT $5 \%$ dengan hasil sebagai berikut : 


\begin{tabular}{|c|c|c|}
\hline Perlakuan & $\begin{array}{c}\text { Rerata Berat Ba- } \\
\text { sah }(\mathrm{cm})\end{array}$ & $\begin{array}{c}\text { BNT }(0,05)= \\
0,14\end{array}$ \\
\hline $\mathrm{D}_{0}$ & 13,40 & $\mathrm{a}$ \\
\hline $\mathrm{D}_{1}$ & 14,25 & $\mathrm{~b}$ \\
\hline $\mathrm{D}_{2}$ & 34,6 & $\mathrm{c}$ \\
\hline $\mathrm{D}_{3}$ & 44,8 & $\mathrm{~d}$ \\
\hline $\mathrm{D}_{4}$ & 34,45 & $\mathrm{c}$ \\
\hline $\mathrm{D}_{5}$ & 13,38 & $\mathrm{a}$ \\
\hline
\end{tabular}

Tabel 13. Hasil Uji BNT 5 \% Berat Basah Kangkung Darat Umur 6 Minggu

Setelah diberi pupuk kotoran kelinci yang bervariasi, berat basah pada perlakuan D3 memberikan hasil yang paling baik. Menurut Salisbury dan Ross (1995), berat basah tanaman berhubungan dengan banyaknya air yang diserap, senyawa yang dibutuhkan tanaman dalam jumlah besar pada setiap organ, tetapi kandungan air dari suatu jaringan tanaman dapat berubah atau tidak stabil sesuai dengan umur dan juga dipengaruhi oleh faktor lingkungan.

\section{Berat Kering}

Hasil pengukuran terhadap berat kering tanaman kangkung darat menunjukkan adanya perbedaan, dapat dilihat sebagai Berikut:

\begin{tabular}{|c|c|}
\hline Perlakuan & $\begin{array}{c}\text { Rerata Berat Kering Tanaman } \\
\text { (gram) }\end{array}$ \\
\hline $\mathrm{D}_{0}$ & 1,43 \\
\hline $\mathrm{D}_{1}$ & 1,47 \\
\hline $\mathrm{D}_{2}$ & 2,25 \\
\hline $\mathrm{D}_{3}$ & 3,7 \\
\hline $\mathrm{D}_{4}$ & 2,07 \\
\hline $\mathrm{D}_{5}$ & 1,99 \\
\hline
\end{tabular}

Tabel 14. Hasil Perhitungan Rerata Berat Kering Tanaman Kangkung Darat (Ipomoea reptans, Poir.) Pada Minggu Ke-6
Keterangan:

D0 $=0 \mathrm{~g}$ (kontrol)

$\mathrm{D} 1=$ perlakuan dosis $20 \mathrm{~g}$

D2 $=$ perlakuan dosis $40 \mathrm{~g}$

D3 = perlakuan dosis $60 \mathrm{~g}$

D4 = perlakuan dosis $80 \mathrm{~g}$

D5 = perlakuan dosis $100 \mathrm{~g}$

Perlakuan dosis pupuk kotoran kelinci memberikan perbedaan yang signifikan terhadap berat kering tanaman kangkung darat. Untuk mengetahui perbedaan antara perlakuan maka dilanjutkan dengan uji BNT 5\%, dengan hasil sebagai berikut:

\begin{tabular}{|c|c|c|}
\hline Perlakuan & $\begin{array}{c}\text { Rerata Berat Ker- } \\
\text { ing }(\mathrm{cm})\end{array}$ & $\begin{array}{c}\text { BNT 0,05 }= \\
0,11\end{array}$ \\
\hline $\mathrm{D}_{0}$ & 1,43 & $\mathrm{a}$ \\
\hline $\mathrm{D}_{1}$ & 1,47 & $\mathrm{a}$ \\
\hline $\mathrm{D}_{2}$ & 2,25 & $\mathrm{c}$ \\
\hline $\mathrm{D}_{3}$ & 3,7 & $\mathrm{~d}$ \\
\hline $\mathrm{D}_{4}$ & 2,07 & $\mathrm{~b}$ \\
\hline $\mathrm{D}_{5}$ & 1,99 & $\mathrm{~b}$ \\
\hline
\end{tabular}

Unsur hara yang diserap akar dalam jaringan tanaman berpengaruh terhadap berat kering tanaman (Lakitan, 1996). Hal ini disebabkan karena komposisi media yang baik, yang dapat menyimpan unsur hara. Berat kering tanaman pada perlakuan D3 menunjukkan pertumbuhan tanaman optimal, yang disebabkan oleh meningkatkan sintesis bahan-bahan organik, sehingga dapat meningkatkan berat kering tanaman. 


\section{KESIMPULAN}

Berdasarkan penelitian diperoleh keskung darat (Ipomoea reptans,Poir.) dengan perlakuan variasi dosis pupuk organik berbahan dasar kotoran kelinci menunjukkan hasil yang berbeda-beda. Dosis pupuk berbahan dasar kotoran kelinci yang tepat pada pertumbuhan tanaman kangkung darat (Ipomoea reptans Poir.) yaitu $60 \mathrm{~g}$.

\section{DAFTAR PUSTAKA}

Anonim, 2000. Karakteristik Plasma Nutfah Kangkung. Buletin Plasma Nutfah Vol. 12 No.1. Balai Penelitian Tanaman Sayuran. Lembang.

Anonim.2008 ${ }^{1}$.Citizen.JournalismOnline.http://citijournal.wordpress. com/2008/01/12/kelinci-dengan-berbagai-manfaat

Ambarwati, E. 2004. Budidaya Tanaman Sayuran. F. Pertanian. UGM Press. Yogyakarta.

Astanto. 1994. Pengelolaan Dan Dokumentasi Plasma Nutfah Tanaman Pangan. Makalah Ballitan Malang No. 94122, BLPP Ketindan. Malang. impulan bahwa pertumbuhan tanaman kang-

Djaja, Willyan. 2008. Langkah Jitu Membuat Kompos dari Kotoran Ternak \& Sampah. Agromedia Pustaka. Jakarta.

Gardner, F.B.R. Pearce dan R.L Mitchell. 1991. Fisiologi Tanaman Budidaya. UI Press. Jakarta.

Indriani, Yovita Hety. 2007. Membuat Kompos Secara Kilat. Penebar Swadaya, Jakarta.

Kurniasih. 2000. Strategi Belajar Mengajar. Rineka Cipta. Jakarta.

Laegreid, M, O, C. Bockman, and O. Kaarstand. 1999. Agriculture Fertilizers and the Environment. CABI Publishing. New York.

Lakitan, B. 1996. Fisiologi Pertumbuhan dan Perkembangan Tanaman. PT Raja Grafindo Persada. Jakarta.

Lingga dan Marsono. 2008. Petunjuk Penggunaan Pupuk. Penebar Swadaya. Jakarta.

Purwandari, Ari Wiyati. 2006. Budidaya Tanaman Kangkung. AZKA Press. Jakarta. 
Ronoprawiro S. 1993. Produksi Tanaman Sayuran di daerah Tropika. UGM Press. Yogyakarta.

Rukmana, Rahmat. 1994. Seri Budidaya Kangkung. Kanisius. Yogyakarta.

Salisbury, Frank B dan Ross, Cleon W. 1995. Fisiologi Tumbuhan Jilid 3. Penerbit ITB. Bandung.

Santoso. 1979. Ilmu Hara. Fakultas Biologi. Yogyakarta.

Setiawan, Ade Iwan. 2005. Memanfaatkan Kotoran Kelinci. Penebar Swadaya. Jakarta.

Sitompul Dan Guritno. 1995. Analisis Pertumbuhan Tanaman. UGM Press. Yogyakarta.

Tjitrosoepomo, G. 1994. Taksonomi Tumbuhan (Spermatophyta). Cetakan II, Gadjah Mada University Press. Yogyakarta 